\title{
Gallbladder Leiomyoma
}

National Cancer Institute

\section{Source}

National Cancer Institute. Gallbladder Leiomyoma. NCI Thesaurus. Code C5747.

A benign smooth muscle neoplasm arising from the gallbladder. It is characterized by the presence of spindle cells with cigar-shaped nuclei, interlacing fascicles, and a whorled pattern. 